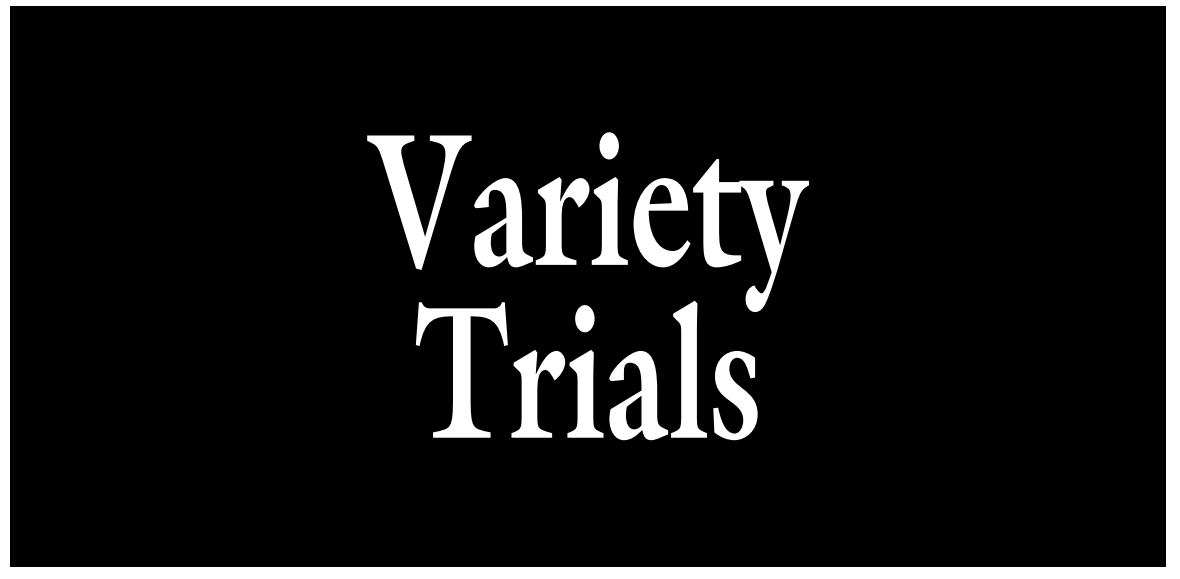

\section{Production and Quality Evaluations of Processing Carrots}

\author{
Lynn Brandenberger ${ }^{1,3}$, William McGlynn ${ }^{1}$, Lynda Wells ${ }^{1}$, \\ Bruce Bostian $^{1}$, and Mark Payton ${ }^{2}$
}

AdDitional InDEX wORDs. Daucus carota, internal root color, yield

SUMMARY. Root yield and quality were evaluated in 15 carrot (Daucus carota) cultivars for use in processing. Marketable yield varied between the fall and spring production seasons for seven of the 15 cultivars with the highest yields recorded in the fall. ' $C$ 8771' and 'Heritage' had the highest yields in Fall 2003.

'Bremen' and 'Neptune' were the highest yielding in Spring 2004. Root length was longest in the fall for a majority of cultivars with 'PS 103397' being the longest in the fall and 'Pipeline' longest in the spring. Forking of roots did not vary significantly for either season. Field color ratings were taken to indicate color differences between the interior core and cortex of the roots. 'Florida', 'Heritage', 'Kamaran', and ' $\mathrm{C} 8771$ ' had consistently less difference between the core and cortex colors. Based on consistent yield and color uniformity, the authors would recommend the use of ' $\mathrm{C}$ 8771' and 'Kamaran' for both spring and fall production seasons in Oklahoma and the use of 'Heritage' and 'Florida' for fall production.

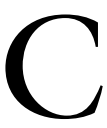

arrot is a cool-season vegetable belonging to the Apiaceae. It probably originated in the Middle East, with the first carrots grown for consumption in Afghanistan (Peirce, 1987). Carrots are a substantial source of dietary fiber and vitamin A in the United States (Peirce, 1987; Yamaguchi, 1983). A

Approved for publication by the directors of the Oklahoma Agricultural Experiment Station.

We thank Rob Maxwell and Rosa Yzquierdo of Seminis Seeds, Darlene Maxwell of Bejo Seed Co. America, Diffong Chen and Diana Dobson of Alf Christianson Seed Co., and Merlyn Schantz of Schantz Family Farm for supplying seed for the trial. A special thanks to Frank Munyak of Allen Canning for help and support in planning and completing these trials.

${ }^{1}$ Department of Horticulture and Landscape Architecture, Oklahoma State University, 360 Agriculture Hall, Stillwater, OK 74078-6027.

${ }^{2}$ Department of Statistics, Oklahoma State University, 301 Math Science Building, Stillwater, OK 74078-1056.

${ }^{3}$ Corresponding author. E-mail: lynn.brandenberger@ okstate.edu
Oklahoma area have recently begun to explore field production of processing carrots in Oklahoma. Production of carrots in the state will lengthen the time that carrots are available for processing and in some cases reduce shipping costs. Carrots have not been a commercial crop in Oklahoma in the past, and information regarding the performance of different carrot cultivars for production and subsequent processing is not available. Therefore, the objective of these studies was to make carrot cultivar recommendations for commercial production and processing by evaluating carrot root yield and quality characteristics.

\section{Materials and methods}

Study site information. Carrot cultivars were evaluated during the fall production season of 2003 and spring production season of 2004 at the Oklahoma Vegetable Research Station located in the northeast area of the state in Bixby. Soil at the research station is a Severn very fine sandy loam (coarse-silty, mixed, calcareous, thermic Typic Udifluvents) that has little organic matter (less than $0.8 \%)$ and a $\mathrm{pH}$ of 5.9 .

Crop Culture. Carrots were direct-seeded on 8 Aug. 2003 and 12 Mar. 2004 using a cone planter (Kincaid Manufacturing, Haven, Kan.). Seeding rates for each test averaged 290,400 seeds/acre. Each plot was 20 $\mathrm{ft}$ long and $6 \mathrm{ft}$ wide, and consisted of two rows of carrots with 15 inches between row centers. Seedbed preparation included chisel plowing, disk harrowing, and finishing using a field cultivator to provide a flat, smooth seedbed before planting. Both studies were irrigated by overhead sprinkler irrigation with plots receiving $\approx 1$ inch of water per week. Plots were fertilized with a total of $90 \mathrm{lb} /$ acre of nitrogen $(\mathrm{N})$ in four split applications. Nitrogen applications used urea $(46 \mathrm{~N}-0 \mathrm{P}-0 \mathrm{~K})$ and included $30 \mathrm{lb} /$ acre $\mathrm{N} 45 \mathrm{~d}$ after planting and $20 \mathrm{lb} /$ acre $\mathrm{N}$ applied three times at 67,76 , and $94 \mathrm{~d}$ after 
planting. Weeds were controlled in the fall with two postemergence applications of linuron at $1 \mathrm{lb} /$ acre a.i. per application and one application of sethoxydim at $0.3 \mathrm{lb} /$ acre a.i. postemergence. Spring weed control included one application of linuron at $\mathrm{llb} /$ acre a.i. postemergence. Plots were handweeded two times in the spring and fall.

EXPERIMENTAL PROCEDURE. Plots were arranged in a randomized complete block design with four replications. Carrot cultivars are listed in Table 1 and include 15 cultivars from four companies. Plots were harvested on 14 Jan. 2004 for the fall study and 12 July 2004 for the spring study by digging $1 \mathrm{~m}$ of one row from each plot. All roots were sorted; data recorded from each plot included number and weight of marketable roots (roots 1 inch in diameter and larger), number of forked roots, length of a 10-root sample, and interior root color ratings. Interior root color ratings were made using a $0-5$ scale, 0 representing no color differences between the core (xylem) and cortex (phloem) and 5 representing a distinct color separation of core and cortex. Further core and cortex color evaluations were conducted on the roots harvested in July 2004 using a Minolta CM-3500d reflectance spectrophotometer (Minolta Corp., Ramsey, N.J.). All color measurements were taken using a $5.0-\mathrm{mm}$ aperture. For each cultivar, five roots were selected at random from each replicate plot. Roots were sliced and the color of the cut surface was evaluated. Three locations were evaluated on each slice: two locations on the cortex and the core. Every location on each sample was evaluated three times and the sample was rotated $120^{\circ}$ between readings to compensate for surface irregularities. These readings were averaged to give a final reading for a given carrot sample. This process was repeated on the five duplicate roots. The duplicates were then averaged to give a final reading for each of the four replications. Readings were taken as C.I.E. $L^{*} a^{*} b^{*}$ values using the $65^{\circ}$ standard illuminant. Hue angle for samples was calcu-

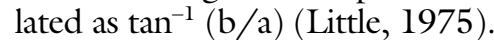

Harvest data were arranged in a randomized complete block design with harvest date serving as a repeatedmeasure variable. Analyses of variance were performed with the use of SAS (PC SAS version 8.2; SAS Institute, Cary, N.C.) and PROC MIXED. The simple effects of cultivar within a harvest date and harvest date within a cultivar were analyzed with a SLICE option in an LSMEANS statement. When the simple effects were significant, pairwise $t$ tests were performed using a PDIFF option. All comparisons were considered significant when an alpha level of 0.05 or less was obtained.

\section{Results and discussion}

There were no differences in carrot yields among the different culti- vars during Fall 2003 (Table 1). Spring 2004 yields were highest for 'Bremen' and 'Neptune' with yields of 10.8 and 9.2 tons/acre, respectively. Yields varied significantly between fall and spring for seven of the 15 cultivars in the studies. All of these except for 'Bremen' had significantly lower yield in the spring than in the fall. Yields in the study were somewhat lower than the average U.S. yield (14.1 tons/ acre) reported by Yamaguchi (1983).

Average root length varied among cultivars in both Fall 2003 and Spring 2004 (Table 1). Eight cultivars in Fall 2003 ranged in length from 6.12 to 6.88 inches with 6.88 and 6.60 inches average lengths being recorded for 'PS103397' and 'Pipeline,' respectively. Sanderson and MacKinnon (2001) reported a somewhat wider range of root lengths of 4.4 to 7.2 inches. 'Pipeline' had significantly longer root length in Spring 2004 (7.00 inches) than all other cultivars. Average root lengths varied for eight of the 15 cultivars between the fall and spring with all cultivars, except 'Pipeline' and 'Neptune', having shorter roots in the spring.

The percentage of forked roots did not vary significantly in the Fall 2003 or the Spring 2004 study (Table 1). A majority of the cultivars did not vary in the percentage of forked roots between either spring or fall, except for ' $\mathrm{C}$ 7105', which had more forking in the spring test than in the fall. From

Table 1. Marketable yield, average root length, and percent forked roots, 2003-2004 carrot cultivar trials, Bixby, Okla.

\begin{tabular}{|c|c|c|c|c|c|c|}
\hline \multirow[b]{2}{*}{ Cultivar/source ${ }^{\mathrm{z}}$} & \multicolumn{2}{|c|}{ Marketable yield ${ }^{\mathrm{y}}$ (tons/acre) } & \multicolumn{2}{|c|}{ Avg root length ${ }^{\mathrm{x}}$ (inches) } & \multicolumn{2}{|c|}{ Forked roots ${ }^{\mathrm{w}}(\%)$} \\
\hline & Fall 2003 & Spring 2004 & Fall 2003 & Spring 2004 & Fall 2003 & Spring 2004 \\
\hline C $7105 /$ A.C. & $7.4 \mathrm{a}^{\mathrm{v}}$ & $6.5 \mathrm{~b}-\mathrm{d}$ & $6.23 \mathrm{a}-\mathrm{e}$ & $6.03 \mathrm{bc}$ & $2.1 \mathrm{a}$ & $12.5 \mathrm{a}^{*}$ \\
\hline Bolero/V.M. & $9.2 \mathrm{a}$ & $7.4 \mathrm{bc}$ & $5.73 \mathrm{de}$ & $5.45 c-f$ & $2.0 \mathrm{a}$ & $7.4 \mathrm{a}$ \\
\hline Bremen/B.J. & $6.9 \mathrm{a}$ & $10.8 a^{*}$ & $6.05 \mathrm{~b}-\mathrm{e}$ & $5.68 \mathrm{~b}-\mathrm{d}$ & $3.4 \mathrm{a}$ & $2.9 \mathrm{a}$ \\
\hline First Class/S.M. & $5.2 \mathrm{a}$ & $3.8 \mathrm{de}$ & $6.38 \mathrm{a}-\mathrm{e}$ & $5.90 \mathrm{~b}-\mathrm{d}$ & $11.1 \mathrm{a}$ & $5.6 \mathrm{a}$ \\
\hline Ingot/A.C. & $8.2 \mathrm{a}$ & $3.9 \mathrm{de}^{*}$ & $6.28 \mathrm{a}-\mathrm{e}$ & $5.33 \mathrm{~d}-\mathrm{f}^{*}$ & $5.9 \mathrm{a}$ & $6.1 \mathrm{a}$ \\
\hline Nantucket/B.J. & $7.9 \mathrm{a}$ & $5.0 \mathrm{c}-\mathrm{e}$ & $5.75 \mathrm{c}-\mathrm{e}$ & $4.83 \mathrm{ef}^{*}$ & $5.0 \mathrm{a}$ & $7.2 \mathrm{a}$ \\
\hline Neptune/A.C. & $7.8 \mathrm{a}$ & $9.2 \mathrm{ab}$ & $6.05 \mathrm{~b}-\mathrm{e}$ & $6.33 \mathrm{~b}$ & $11.5 \mathrm{a}$ & $7.0 \mathrm{a}$ \\
\hline Pipeline/S.M. & $7.6 \mathrm{a}$ & $5.7 \mathrm{c}-\mathrm{e}$ & $6.60 \mathrm{ab}$ & $7.00 \mathrm{a}$ & $8.8 \mathrm{a}$ & $7.3 \mathrm{a}$ \\
\hline PS $103397 /$ S.M. & $7.7 \mathrm{a}$ & $4.7 \mathrm{c}-\mathrm{e}$ & $6.88 \mathrm{a}$ & $5.95 \mathrm{~b}-\mathrm{d}^{*}$ & $5.6 \mathrm{a}$ & $3.5 \mathrm{a}$ \\
\hline
\end{tabular}

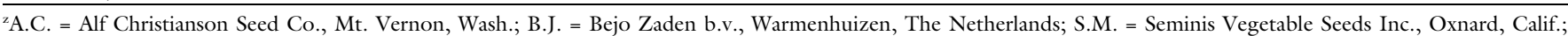
V.M. = Vilmorin, La Ménitré, France.

${ }^{y}$ Marketable yield based on weight of carrots harvested that were 1 inch $(2.5 \mathrm{~cm})$ in diameter or larger, $1 \mathrm{ton} / \mathrm{acre}=2.2417 \mathrm{Mg} \cdot \mathrm{ha}{ }^{-1}$

${ }^{x}$ Average root length based on the overall length of 10 roots harvested as a representative sample from each plot, 1 inch $=2.54 \mathrm{~cm}$.

wercentage forked roots based on the number of forked roots harvested from each plot.

"Numbers within a column followed by the same letter were not significantly different at the $5 \%$ level. Numbers with an asterisk (*) next to letters indicate a significant difference between fall and spring plantings. 
a practical basis, producers may be interested in using the root forking data to make decisions, although the statistics would not support this at the 0.05 alpha level.

Root color varied in both Fall 2003 and Spring 2004 (Table 2). Interior root color ratings for seven cultivars in Fall 2003 were significantly higher than for 'Ingot', which had a 1.4 rating indicating little color difference between the core (xylem) and cortex (phloem). 'Neptune', 'Heritage', and 'Florida' had ratings of $1.3,1.4$, and 1.5 , respectively, in Spring 2004 and had significantly less color differences than five other cultivars in the spring. Three of the 15 cultivars in the studies varied between fall and spring for interior root color ratings. Both 'First Class' and 'Neptune' had lower ratings in the spring compared with the fall.

In contrast to the subjective field ratings, laboratory tests recorded no statistically significant differences between core and cortex hue angles and $\mathrm{L}^{*}$ values within any of the cultivars evaluated (data not shown). In addition, no significant differences were seen for hue angles or $\mathrm{L}^{*}$ values among the carrot cultivars (data not shown). Accordingly, hue angle and $\mathrm{L}^{*}$ value were averaged overall cultivars and root locations. The resulting $95 \%$ confidence interval for the mean hue angle was $56.5^{\circ} \pm 0.12^{\circ}$. For the

Table 2. Carrot in-field ratings for interior root color, 2003-2004 carrot cultivar trials, Bixby, Okla.

\begin{tabular}{lcc}
\hline & \multicolumn{2}{c}{ Interior root color rating ${ }^{\mathrm{y}}$ (0-5 scale $)$} \\
\cline { 2 - 3 } Cultivar/source & Fall $\mathbf{2 0 0 3}$ & Spring 2004 \\
\hline C 7105/A.C. & $3.1 \mathrm{ab}^{\mathrm{x}}$ & $2.8 \mathrm{a}-\mathrm{c}$ \\
C 8771/A.C. & $1.9 \mathrm{c}-\mathrm{e}$ & $2.1 \mathrm{~b}-\mathrm{d}$ \\
Bolero/V.M. & $3.6 \mathrm{a}$ & $3.8 \mathrm{a}$ \\
Bremen/B.J. & $2.9 \mathrm{a}-\mathrm{c}$ & $2.3 \mathrm{~b}-\mathrm{d}$ \\
First Class/S.M. & $3.8 \mathrm{a}$ & $1.9 \mathrm{~cd}^{*}$ \\
Florida/B.J. & $1.7 \mathrm{de}$ & $1.5 \mathrm{~d}$ \\
Heritage/S.M. & $2.1 \mathrm{~b}-\mathrm{e}$ & $1.4 \mathrm{~d}$ \\
Ingot/A.C. & $1.4 \mathrm{e}$ & $2.8 \mathrm{a}-\mathrm{c}^{*}$ \\
Nantucket/B.J. & $2.8 \mathrm{a}-\mathrm{d}$ & $3.1 \mathrm{ab}$ \\
Neptune/A.C. & $2.6 \mathrm{a}-\mathrm{d}$ & $1.3 \mathrm{~d}$ \\
Pipeline/S.M. & $2.4 \mathrm{~b}-\mathrm{e}$ & $2.1 \mathrm{~b}-\mathrm{d}$ \\
PS 103397/S.M. & $2.1 \mathrm{~b}-\mathrm{e}$ & $2.3 \mathrm{~b}-\mathrm{d}$ \\
Recoleta/S.M. & $2.3 \mathrm{~b}-\mathrm{e}$ & $2.0 \mathrm{~b}-\mathrm{d}$ \\
Samantha/A.C. & $2.6 \mathrm{a}-\mathrm{d}$ & $3.8 \mathrm{a}$ \\
Kamaran/B.J. & $2.1 \mathrm{~b}-\mathrm{e}$ & $1.6 \mathrm{~cd}$ \\
\hline
\end{tabular}

${ }^{\mathrm{z} A . C .}=$ Alf Christianson Seed Co., Mt. Vernon, Wash.; B.J. = Bejo Zaden b.v., Warmenhuizen, The Netherlands; S.M. = Seminis Vegetable Seeds Inc., Oxnard, Calif.; V.M. = Vilmorin, La Ménitré, France.

'Root color ratings based on a $0-5$ scale with 0 indicating no color differences between the core and cortex and 5 indicating major differences in color between the core and cortex.

${ }^{x}$ Numbers within a column followed by the same letter are not significantly different at the 0.05 level. Numbers with an asterisk $(*)$ next to letters indicate a significant difference between fall and spring results.

$L^{*}$ value, the $95 \%$ confidence interval for the mean was $40.9 \pm 0.35$.

Carrot yield and root length varied significantly between the two seasons for several cultivars. Studies by Nel et al. (1998) noted variation for grain crops in yield and other characseasons. Zdravkovic et al. (1997) observed differences in yield from 1 year to the next for carrot cultivars as a result of environmental variation. Seasonal differences in environment are common in Oklahoma where fall oesons begin in Septemlower amounts of rainfall and end with lower temperatures and higher moisture levels. The inverse is true for ing production seasons. 'Neptune' 'C 8771' in the fall had the highest yield recorded for both seasons.

Differences in color between the core and cortex were more consistent between seasons than were yield and length. Large color differences sidered aesthetically undesirable by the consumer particularly after cooking. 'Florida', 'Heritage', 'Kamaran', and 'C 8771' had consistently less difference between the core and cortex colors based on field ratings. Because

Hortechnology · January-March 2007 17(1) no statistically significant differences were seen in the objective color values for the carrot roots, no correlation between subjective "field" and objective "laboratory" testing was possible. It is possible that the significant visual differences among cultivars observed in the Spring 2004 harvest are the result of visual cues not readily detectable by reflectance spectra from discrete areas on the root. Further work is necessary to determine whether subjective appearance results might be better correlated with objective color testing.

Based on consistent yield and color uniformity, the authors would recommend the use of ' $\mathrm{C}$ 8771' and 'Kamaran' for both spring and fall production seasons in Oklahoma and the use of 'Heritage' and 'Florida' for fall production.

\section{Literature cited}

Little, A. 1975. Off on a tangent. J. Food Sci. 40:410-411.

Nel, M.M., G.A. Agenbag, and J.L. Purchase. 1998. Sources of variation for yield, protein content and hectolitre mass of spring wheat (Triticum aestivum L.) cultivars of the western and southern cape. South African J. Plant Soil 15:72-79.

O’Neill, M.E., Y. Carroll, B. Corridan, B. Olmedilla, F. Granado, I. Blanco, H. Van den Berg, I. Hininger, A.M. Rousell, M. Chopra, S. Southon, and D.I. Thurnham. 2001. A European carotenoid database to assess carotenoid intakes and its use in a five-country comparative study. Br. J. Nutr. 85:499-507.

Peirce, L.C. 1987. Vegetables: Characteristics, production, and marketing, lst ed. Wiley, N.Y.

Sanderson, K.R. and S.D. MacKinnon. 2001. Evaluation of carrot cultivars for cut and peel processing in Prince Edward Island, Canada, 1997-1998. HortTechnology 11:657-660.

U.S. Department of Agriculture. 2006. Vegetables 2005 summary. 9 May 2006. <http://jan.mannlib.cornell.edu/reports/ nassr/fruit/pvg-bban/vgan0103.pdf>.

Yamaguchi, M. 1983. World vegetables: Principles, production, and nutritive values, lst ed. AVI, Westport, Conn.

Zdravkovic, M., M. Damjanovic, and D. Corokalo. 1997. The influence of fertilization on the yield of different carrot varieties. Acta Hort. 462:93-96. 